\title{
Pott's puffy tumour by Streptoccocus intermedius a rare complication of sinusitis
}

\author{
Roberta Onesimo, ${ }^{1}$ Maria Scalzone, ${ }^{1}$ Piero Valetini, ${ }^{1}$ Massimo Caldarelli ${ }^{2}$ \\ ${ }^{1}$ Pediatrics Department, Catholic University of Sacred Heart, Rome, Italy; \\ ${ }^{2}$ Neurosurgery Department, Catholic University of Sacred Heart, Rome, Italy \\ Correspondence to Dr Roberta Onesimo, roberta onesimo@yahoo.it
}

\section{DESCRIPTION}

An 8-year-old child presented with persistent fever, headache and a frontal swelling. The medical history was significant for recurrent episodes of upper respiratory tract infections and frontal headache. On physical examination, she showed a good performance condition and normal neurologic status. On palpation, a tender, fluctuating, doughy and warm mass $(9 \times 7 \mathrm{~cm})$ in the forehead over the frontal sinus was found (figure 1). The head MRI revealed frontal, subcutaneous and epidural abscesses associated to inflammatory thickening of frontal sinus and ethmoidal cells (figure 2). Skin and soft-tissue infection, infected hematoma, tumours of the skin, soft-tissue and bone have been ruled out. The child was treated with antibiotic therapy coupled with subcutaneous and epidural accesses evacuation, with complete recovery. Pus culture grew Streptococcus intermedius. The organisms of this group are found in the human oral cavity and have a strikingly prominent association with brain abscess. ${ }^{1}$ In our case, tooth infection has been ruled out. Pott's puffy tumour is an uncommon complication of frontal sinusitis and of forehead trauma. It is a fairly rare but potentially life-threatening entity even in postantibiotic era, characterised by a swelling of the scalp due to a subperiosteal abscess associated to osteomyelitis in the frontal bone. ${ }^{2}$ When a child presents with a fluctuating swelling of the forehead, imaging by CT or MRI should be done to confirm the diagnosis and exclude neurological complications. Antibiotic therapy and neurosurgery are essential to reduce mortality and morbility. ${ }^{3}$

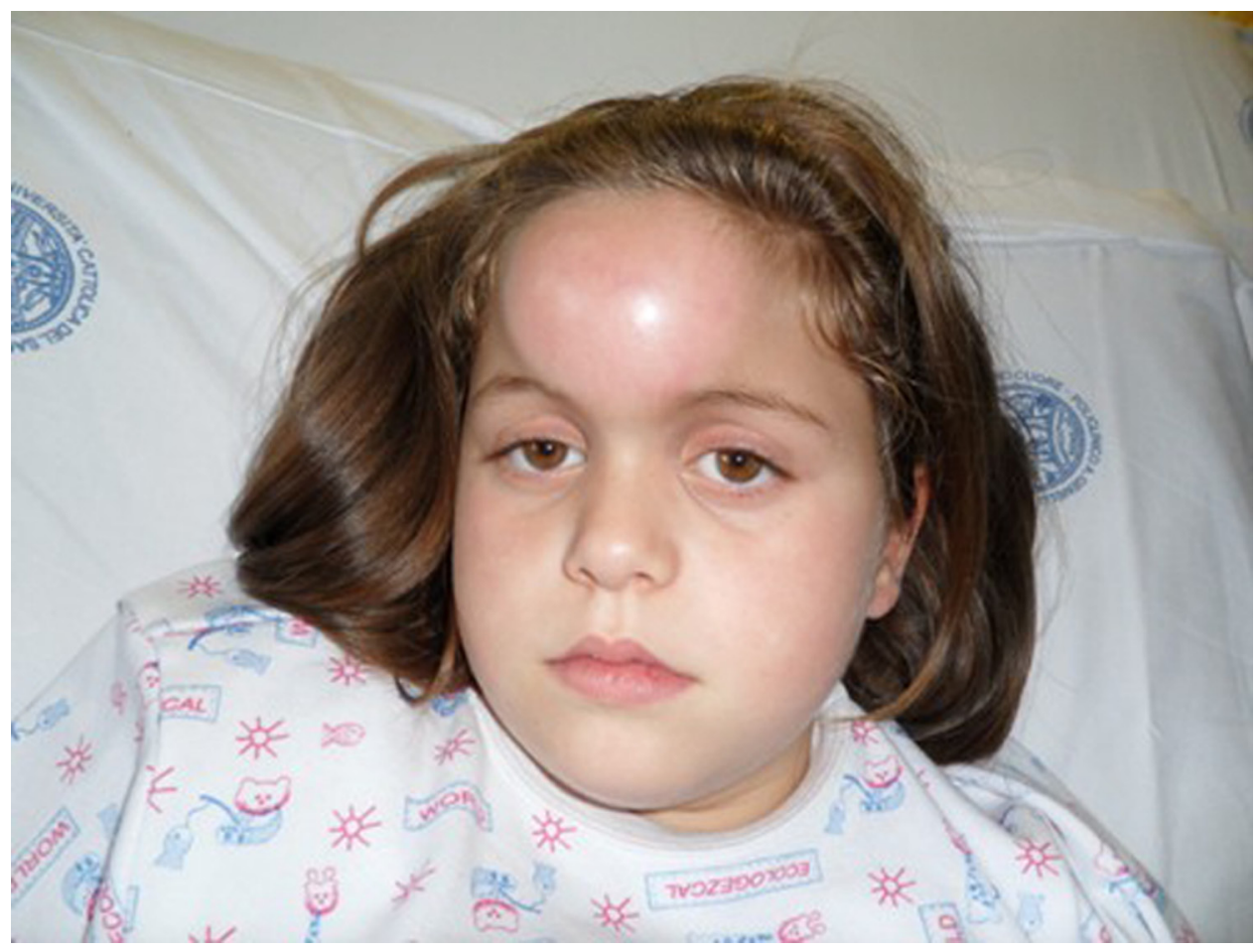

Figure 1 Pott's puffy tumour. The child at the diagnosis. 


\section{BMJ Case Reports}

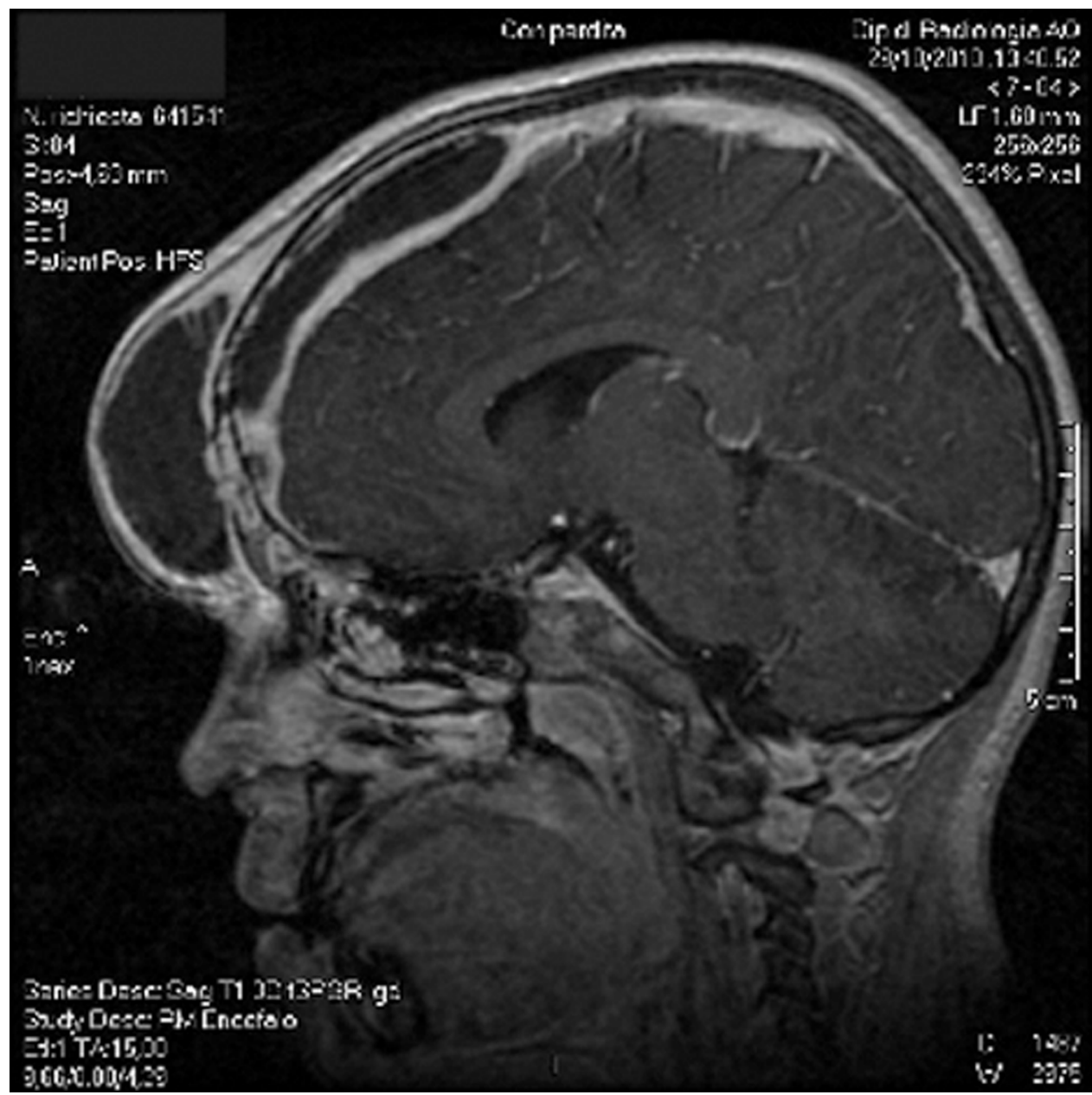

Figure 2 MRI: frontal, subcutaneous and epidural abscesses associated to breach in the continuity in anterior wall of frontal sinus.

\section{Competing interests None.}

Patient consent Obtained.

\section{REFERENCES}

1. Tran MP, Caldwell-McMillan M, Khalife W, et al. Streptococcus intermedius causing infective endocarditis and abscesses: a report of three cases and review of the literature. BMC Infect Dis 2008;8:154.

This pdf has been created automatically from the final edited text and images.

Copyright 2011 BMJ Publishing Group. All rights reserved. For permission to reuse any of this content visit http://group.bmj.com/group/rights-licensing/permissions.

BMJ Case Report Fellows may re-use this article for personal use and teaching without any further permission.

Please cite this article as follows (you will need to access the article online to obtain the date of publication).

Onesimo R, Scalzone M, Valetini P, Caldarelli M. Pott's puffy tumour by Streptoccocus intermedius a rare complication of sinusitis. BMJ Case Reports 2011;10.1136/bcr.08.2011.4660, date of publication

Become a Fellow of BMJ Case Reports today and you can:

- Submit as many cases as you like

- Enjoy fast sympathetic peer review and rapid publication of accepted articles

- Access all the published articles

- Re-use any of the published material for personal use and teaching without further permission

For information on Institutional Fellowships contact consortiasales@bmjgroup.com

Visit casereports.bmj.com for more articles like this and to become a Fellow 